\title{
International prevalence of recurrent wheezing during the first year of life: variability, treatment patterns and use of health resources
}

\author{
Javier Mallol, ${ }^{1}$ Luis García-Marcos, ${ }^{2}$ Dirceu Solé, ${ }^{3}$ Paul Brand, ${ }^{4}$ the EISL Study Group
}

'Department of Pediatric Respiratory Medicine, Hospital El Pino, University of Santiago de Chile (USACH), Santiago, Chile

${ }^{2}$ Pediatric Respiratory and Allergy Units, Virgen de la Arrixaca University Children's Hospital, University of Murcia, and CIBER of Epidemiology and Public Health (CIBERESP), Murcia, Spain

${ }^{3}$ Division of Allergy, Clinical Immunology and Rheumatology. Department of Pediatrics, Federal University of São Paulo (UNIFESP), São Paulo, Brazil ${ }^{4}$ Department of Pediatric Pulmonology, Isala Clinic, Zwolle, The Netherlands

\section{Correspondence to}

Professor Javier Mallol, P 0 Box 23 Correo 9, Santiago, Chile; jmallol@vtr.net

Members of the EISL Study Group are listed at the end of the paper.

Received 11 February 2009 Accepted 29 July 2010 Published Online First 20 September 2010
ABSTRACT

Background Recurrent wheezing (RW) during the first year of life is a major cause of respiratory morbidity worldwide, yet there are no studies on its prevalence at an international level. A study was undertaken to determine the prevalence of RW in infants during their first year of life in affluent and non-affluent localities.

Methods This international population-based study was performed in random samples of infants aged 12-15 months from 17 centres in Latin America and Europe. It uses a validated questionnaire answered by parents at the primary care health clinics where infants attend for growth/development monitoring and/or vaccine administration.

Results Among the 30093 infants surveyed, 45.2\% (95\% Cl $44.7 \%$ to $45.8 \%)$ had at least one episode of wheezing and $20.3 \%$ (95\% Cl $19.8 \%$ to $20.7 \%$ ) had RW. The mean prevalence of RW in Latin American and European centres was $21.4 \%(95 \% \mathrm{Cl} 20.9 \%$ to $21.9 \%)$ and $15.0 \%$ (95\% Cl $14.0 \%$ to $15.9 \%)$, respectively $(p<0.001)$. There was significant morbidity associated with RW in terms of severe episodes $(59.4 \%)$, visits to the emergency department $(71.1 \%)$ and hospital admissions (26.8\%); $46.1 \%$ used inhaled corticosteroids.

Conclusions The prevalence of RW in infants during the first year of life is high and varies between localities. A significant proportion of infants progress to a more severe condition which results in high use of health resources (visits to emergency department and hospitalisations). The prevalence of RW is lower and less severe in European than in Latin American centres, suggesting there is a higher risk for the disease in developing areas.

\section{INTRODUCTION}

Despite the fact that recurrent wheezing (RW) in the first year of life-defined as three or more episodes of wheezing during that time-and its associated morbidity is a significant global public health problem, there is no international information on its prevalence and severity obtained from the general population with standardised methods and including centres in both high- and low-income countries. It is well recognised that RW in infants significantly affects the quality of life of patients and their families ${ }^{1}$ and represents an important cause for using healthcare resources, thus resulting in a large health economic impact. ${ }^{2}{ }^{3}$ In a prevalence study in young children aged $1-5$ years from the USA and Europe, it was found that one-third of them suffered from recurrent asthma-like symptoms. ${ }^{4}$ Similarly, a high prevalence of RW has been found in the UK among preschool children aged 1-4 years. In that study, the prevalence of current wheezing (one or more episodes) in 1-year-old children was $25.5 \%$ in South Asians and $35.6 \%$ in white infants. ${ }^{5}$

The prevalence of wheezing in the first year of life seems to be higher in developing countries, as found in a birth cohort study from Latin America undertaken in a low socioeconomic urban population. ${ }^{6}$ Although the prevalence of RW in infants might be increased in low-resourced populations, ${ }^{6-8}$ to the best of our knowledge there is no comparative information which includes infants from different centres in both developing and developed countries.

The hypothesis of the Estudio Internacional de Sibilancias en Lactantes (EISL) study (or International Study of Wheezing in Infants) is that the prevalence of RW during the first year of life is as variable as the prevalence of asthma symptoms in older children, ${ }^{910}$ and differs between affluent and non-affluent countries. Here we describe the findings of the aforementioned study, which was performed with a standardised methodology and a validated questionnaire ${ }^{11} 12$ across different centres in Latin America and Europe.

\section{METHODS}

The EISL is a multicountry multicentric crosssectional population-based study carried out using the same methodology in all its centres. The main objective of the EISL is to determine the prevalence of RW and related characteristics in the first year of life (defined as three or more parent-reported wheezing episodes during that time) and to compare it between centres. It uses a standardised questionnaire on wheezing that also includes questions on common cold or upper respiratory tract infection (URTI), treatment modalities such as inhaled bronchodilators (BD), inhaled corticosteroids (ICS) and leukotriene receptor antagonists (LTRA), severe episodes, sleep disturbance, emergency department (ED) visits and admissions to hospital due to wheezing, among others. For questions on URTI, parents were asked if their babies had had acute episodes of common cold with runny nose (watery nasal rhinorroea), sneezing, nasal obstruction, mild cough, with or without mild fever. A parental history of asthma was defined as a positive response to the question on maternal or paternal asthma. The questions on wheezing had been previously validated in physician-diagnosed wheezing (general paediatricians and paediatric pulmonologists) in centres in Latin America and Spain. ${ }^{11} 12$ The Portuguese version of the questionnaire was translated from Spanish into 
Portuguese and back-translated from Portuguese into Spanish. The same was done with the Dutch version.

The methodology used in the EISL was partially based on that employed in phases I and III by the International Study of Asthma and Allergies in Childhood (ISAAC) ${ }^{13}{ }^{14}$-that is, random samples, centres in different countries, same methods and questionnaire used by the different participating centres and study supervised by local and national coordinators. The centres that participated in the present study also participated in either ISAAC phase I or III, or both.

The study samples were drawn from the populations living in defined geographical areas (centres) from Latin America (LA), Spain and The Netherlands through scientific networks and focusing on locations of particular interest. A centre in The Netherlands was included for comparison with Spanish centres and, although ethnically different, the European (EU) centres participating in this study share similar high cultural and socioeconomic development and thus can be considered as representatives of fully-developed and well-resourced western countries. Each collaborating centre was responsible for completing a registration document and obtaining its own funding.

The sample size was calculated with reference to RW rather than to the prevalence of one or more episodes of wheezing. If the real prevalence of RW in the first year of life is $20 \%$ in one centre and $15 \%$ in another, samples of approximately 1000 individuals per centre would have an $80 \%$ power to detect a true difference at a significance level of $5 \%$. This number was therefore the sample size sought in each centre.

\section{Subjects and sampling frame}

All the primary care health clinics where infants attend for growth/development monitoring and/or vaccine administration, according to the national public health programmes in each country, and located in the geographical area corresponding to an EISL centre were considered for recruiting infants and their parents or guardians. A random sample of those centres was selected providing they could recruit at least 1000 children aged 12-15 months at the time of responding to the questionnaires. Parents or guardians were asked to complete the questionnaire when infants were brought for a scheduled vaccine administration or a preventive healthcare visit at that age, emphasising that questions were only related to events that had occurred during the first 12 months of life of their children and without assistance from centre staff.

In order to test the effect of two different viral seasons, four centres planned their fieldwork to be extended to two consecutive years so they had approximately half of the sample in each year.

Centres performed the survey between March 2005 and March 2007 and those which provided a clean data set by the end of 2007 were included in the present report.

\section{Data analysis}

Data from the different participating centres were analysed by SPSS V.13. Descriptive statistics, including 95\% CIs, were employed to show the differences between centres and between groups of centres within countries or regions. Crude ORs were used to estimate the strength of the wheezing-related factors in LA and EU. The $\chi^{2}$ test was used to assess the significance of associations and differences between proportions; $\mathrm{p}<0.05$ was considered statistically significant.

The results are expressed as mean (95\% CI) except for age which is reported as mean $\pm \mathrm{SD}$.

\section{RESULTS}

There were 17 official EISL centres which supplied 30093 correctly completed questionnaires (25030 from 12 centres in Latin America and 5063 from 5 centres in Europe). The mean response rate was $83.2 \%$. The mean age for the whole sample of infants $(47.5 \%$ female) was $13.4 \pm 1.7$ months; $13.3 \pm 1.3$ months in LA and $14.5 \pm 3.0$ months in EU. The proportion of questionnaires filled out by mothers was $86.5 \%$, by fathers was $5.8 \%$ and by guardians was $7.7 \%$.

In the whole sample (all the participating infants from LA and EU) it was found that $45.2 \%$ (95\% CI $44.7 \%$ to $45.8 \%$ ) wheezed at least once during their first year of life; $20.3 \%$ (95\% CI $20.8 \%$ to $21.7 \%$ ) had RW; $8.5 \%$ (95\% CI $8.2 \%$ to $8.8 \%$ ) reported physician-diagnosed asthma; and $16.7 \%$ (95\% CI $16.3 \%$ to $17.2 \%$ ) of infants had their first episode of wheezing during the first 3 months of life. The prevalence of RW in LA varied from $2.3 \%$ in Merida (Mexico) to $36.3 \%$ in Porto Alegre (Brazil), while in the EU centres it ranged from $12.1 \%$ in Valencia (Spain) to $18.6 \%$ in Bilbao (Spain). There was a high variability between centres with respect to the prevalence of RW, physician-diagnosed asthma, severity of wheezing episodes, admissions to hospital due to wheezing and the other related variables both in centres within the same country and between countries. Two centres (Fortaleza and Recife) could not provide data on the prevalence of parental asthma (table 1).

There was a significant association between having an URTI in the first 3 months of life and wheezing in the same period, and also with RW later. The proportion of infants who had an URTI during the first 3 months of life was significantly higher in LA (38.2\%, 95\% CI $37.6 \%$ to $38.8 \%)$ than in $\mathrm{EU}(30.0 \%$, 95\% CI $28.7 \%$ to $31.3 \%)$. Parental history of asthma was reported in 16.6\% (95\% CI 16.2\% to $17.1 \%)$ of infants, and was significantly larger in LA $(18.2 \%, 95 \%$ CI $17.7 \%$ to $18.7 \%)$ than in $\mathrm{EU}(10.2 \%, 95 \%$ CI $9.4 \%$ to $11.0 \%)$. Reported physician-diagnosed asthma was also significantly higher in LA $(9.20 \%, 95 \%$ CI $8.9 \%$ to $9.6 \%)$ than in EU centres $(4.70 \%$, $95 \%$ CI $4.2 \%$ to $5.4 \%)$. The proportion of infants with RW and reported eczema was significantly higher in LA $(56.9 \%, 95 \% \mathrm{CI}$ $56.0 \%$ to $57.8 \%)$ than in EU $(20.2 \%, 95 \%$ CI $18.4 \%$ to $22.2 \%)$.

The prevalence of the severity markers of wheezing (severe episodes, visits to ED and hospital admissions) was significantly lower in EU than in LA (table 1), and this difference was even greater when comparing only infants with RW (table 2).

When considering only infants with RW (figure 1), there were also large differences between LA and EU centres-and also within the same countries-regarding use of medications, prevalence of URTI in the first 3 months of life, parental history of asthma, physician-diagnosed asthma, severe episodes and use of health resources (table 2). The reported use of ICS in infants with RW during the first year of life was $46.1 \%$ in the entire population, but it was significantly lower in LA centres $(45.0 \%, 95 \% \mathrm{CI}$ $43.6 \%$ to $46.3 \%$ ) than in $\mathrm{EU}(54.2 \%$, $95 \%$ CI $50.5 \%$ to $57.9 \%$ ). There was no significant difference between LA and EU in the proportion of infants with RW who had been admitted to hospital and who received ICS $(65.5 \%, 95 \%$ CI $63.0 \%$ to $67.9 \%$ vs $70.2 \%, 95 \%$ CI $61.4 \%$ to $79.7 \%$ ), nor for those who received other medications (BD and LTRA). In the whole sample, the proportion of infants who used ICS was significantly higher in those who had severe episodes (OR 11.80, 95\% CI 11.76 to 12.64), frequent sleep disturbance (OR 5.85, 95\% CI 5.35 to 6.42), visits to the ED (OR 11.81, 95\% CI 10.97 to 12.70) and admissions (OR 10.85, $95 \%$ CI 9.93 to 11.86$)$ compared with those who did not have these wheezing severity indices. In infants with RW, the use of ICS was also significantly higher in those who had severe episodes (OR 2.27, 95\% CI 2.03 to 2.53), frequent sleep disturbance (OR 
Table 1 Number of infants per centre, participation rate and prevalence (\%) of the different variables related to wheezing during the first year of life $(n=30093)$

\begin{tabular}{|c|c|c|c|c|c|c|c|c|c|c|}
\hline & $\mathbf{N}$ & $\begin{array}{l}\text { Response } \\
\text { rate }(\%)\end{array}$ & $\begin{array}{l}\text { One or more } \\
\text { wheezing } \\
\text { episodes }\end{array}$ & $\begin{array}{l}\text { Recurrent } \\
\text { wheezing } \\
\text { ( } \geq 3 \text { episodes) }\end{array}$ & $\begin{array}{l}\text { Wheezing } \\
\text { during first } \\
3 \text { months }\end{array}$ & $\begin{array}{l}\text { Physician- } \\
\text { diagnosed } \\
\text { asthma }\end{array}$ & $\begin{array}{l}\text { Parental } \\
\text { asthma }\end{array}$ & $\begin{array}{l}\text { Severe } \\
\text { wheezing } \\
\text { episode }\end{array}$ & $\begin{array}{l}\text { Visit to ED } \\
\text { due to } \\
\text { wheezing }\end{array}$ & $\begin{array}{l}\text { Hospital } \\
\text { admission } \\
\text { due to } \\
\text { wheezing }\end{array}$ \\
\hline Santiago & 2988 & 87 & 60.80 & 22.00 & 25.40 & 2.9 & 9.5 & 23.20 & 30.40 & 8.40 \\
\hline Valdivia & 3075 & 89 & 54.40 & 21.10 & 20.60 & 2.7 & 14.8 & 23.30 & 31.30 & 12.10 \\
\hline \multicolumn{11}{|l|}{ Brazil } \\
\hline Fortaleza & 1209 & 90 & 45.20 & 22.10 & 18.80 & 5.2 & - & 21.90 & 27.90 & 8.40 \\
\hline Belem & 3029 & 88 & 46.10 & 21.90 & 19.30 & 10.1 & 13.1 & 21.20 & 29.20 & 8.10 \\
\hline Porto Alegre & 1016 & 85 & 63.60 & 36.30 & 23.90 & 22.4 & 25.3 & 36.60 & 45.00 & 17.60 \\
\hline Sao Paulo & 1012 & 89 & 46.00 & 26.70 & 17.40 & 3.5 & 8.2 & 22.40 & 29.40 & 9.10 \\
\hline Curitiba & 3003 & 90 & 45.40 & 22.60 & 13.60 & 4.9 & 17.7 & 20.90 & 26.00 & 5.70 \\
\hline \multicolumn{11}{|l|}{ Colombia } \\
\hline Barranquilla & 1688 & 85 & 46.70 & 15.90 & 21.50 & 10.2 & 16.6 & 33.30 & 36.00 & 18.00 \\
\hline $\begin{array}{l}\text { Latin America total, mean } \\
(95 \% \mathrm{Cl})\end{array}$ & 25030 & $\begin{array}{l}88.3(87.1 \text { to } \\
89.6)\end{array}$ & $\begin{array}{l}47.30 \text { (46.7 to } \\
48.0)\end{array}$ & $\begin{array}{l}21.4(20.9 \text { to } \\
21.9)\end{array}$ & $\begin{array}{l}17.90(17.5 \text { to } \\
18.4)\end{array}$ & $\begin{array}{l}9.20 \text { (8.9 to } \\
9.6)\end{array}$ & $\begin{array}{l}18.1(17.6 \text { to } \\
18.6)\end{array}$ & $\begin{array}{l}23.60(23.1 \text { to } \\
24.1)\end{array}$ & $\begin{array}{l}29.30(28.7 \text { to } \\
29.9)\end{array}$ & $\begin{array}{l}10.40(10.0 \text { to } \\
11.0)\end{array}$ \\
\hline \multicolumn{11}{|l|}{ Spain } \\
\hline Bilbao & 996 & 70 & 38.90 & 18.60 & 8.50 & 5.6 & 9.8 & 10.30 & 16.20 & 2.80 \\
\hline Cartagena & 1172 & 71 & 39.10 & 16.20 & 14.40 & 6.0 & 10.3 & 16.20 & 19.40 & 3.80 \\
\hline La Coruña & 930 & 72 & 34.80 & 13.80 & 9.40 & 3.6 & 11.8 & 11.30 & 14.80 & 5.00 \\
\hline Valencia & 886 & 61 & 28.70 & 12.10 & 10.00 & 1.0 & 8.2 & 12.70 & 21.40 & 5.40 \\
\hline \multicolumn{11}{|l|}{ The Netherlands } \\
\hline Zwolle & 1079 & 81 & 29.00 & 13.80 & 9.20 & 6.7 & 10.6 & 12.00 & 12.30 & 4.20 \\
\hline $\begin{array}{l}\text { Europe total, mean (95\% } \\
\text { Cl) }\end{array}$ & 5063 & $\begin{array}{l}71(62.2 \text { to } \\
79.8)\end{array}$ & $\begin{array}{l}34.40 \text { (33.0 to } \\
35.6)\end{array}$ & $\begin{array}{l}15.0(14.0 \text { to } \\
15.9)\end{array}$ & $\begin{array}{l}10.50 \text { (9.7 to } \\
11.4)\end{array}$ & $4.70(4.2$ to 5.4$)$ & $\begin{array}{l}10.2 \text { (9.4 to } \\
11.0)\end{array}$ & $\begin{array}{l}12.60(11.8 \text { to } \\
13.7)\end{array}$ & $\begin{array}{l}16.90(16.0 \text { to } \\
18.1)\end{array}$ & $\begin{array}{l}4.10(3.5 \text { to } \\
4.6)\end{array}$ \\
\hline
\end{tabular}

ED, emergency department.

$1.38,95 \%$ CI 1.22 to 1.55 ), visits to the ED (OR $1.76,95 \%$ CI 1.56 to 1.99 ) and admissions (OR $3.08,95 \%$ CI 2.72 to 3.50 ).

In centres where prescribing ICS has no or minimal cost for parents, the percentage of infants with RW who had visited the $\mathrm{ED}$ and had received ICS was not significantly higher in EU $(61.5 \%, 95 \%$ CI $56.4 \%$ to $66.3 \%)$ than in LA $(56.1 \%$, $95 \%$ CI $54.3 \%$ to $58.0 \%$ ) whereas in centres where ICS were not available (table 2) the percentage was significantly lower $(28.7 \%, 95 \%$ CI $25.9 \%$ to $31.6 \%$ ). A physician diagnosis of asthma was reported in $25.9 \%$ of all infants with RW $(26.5 \%$ in LA and $21.7 \%$ in EU). Besides, a diagnosis of asthma was made in $34 \%$ of those with RW and severe episodes; in $40 \%$ of those with RW and admissions due to wheezing; in 30\% of those with reported visits to the ED; and in $32.8 \%$ of those who also had a parental history of asthma. The percentage of infants with RW whose parents reported at least one severe episode and also visited the ED was significantly higher in LA $(88.9 \%, 95 \%$ CI $87.8 \%$ to $89.9 \%)$ than in $\mathrm{EU}(81.0 \%, 95 \%$ CI $76.5 \%$ to $84.9 \%)$. The percentage of infants with RW and physician-diagnosed asthma who visited the $\mathrm{ED}(82.8 \%)$ was significantly higher than those with RW but without a diagnosis of asthma (67.9\%). Also, there was a significantly higher proportion of hospital admissions in infants with RW and an asthma diagnosis (41.7\%) than in those without an asthma diagnosis $(22.0 \%)$.

The prevalence of wheezing-related factors was significantly higher in LA than in EU. The associations between several factors and children from LA centres compared with EU centres (base) are shown in table 3 .
In the four centres (two from LA and two from $\mathrm{EU}$ ) where the prevalence of RW between two consecutive years (two viral seasons) was assessed, it was found that the difference was small and not significant: $1.5 \%$ in Cartagena (Spain); $0.6 \%$ in Zwolle (The Netherlands); $1.3 \%$ in Santiago (Chile); and 2.9\% in Curitiba (Brazil).

\section{DISCUSSION}

This first international comparison of the prevalence of RW during the first year of life found a high prevalence of this condition, with a large variability among centres and lower prevalence and severity in EU than in LA centres. This study also found a high proportion of infants with RW whose condition was severe, as reflected by sleep disturbance, severe episodes, ED visits and admissions to hospital. This is the first time that this type of information is available at an international level, including infants from centres in countries with different cultural and socioeconomic levels.

The high proportion of ED visits and hospital admissions due to wheezing, severe episodes and frequent sleep disturbance reported by parents of infants with RW in centres in LA and EU suggest a rather poor management of infants with troublesome RW, as found by previous studies in wheezy young children. ${ }^{4}$ Although the role of ICS in infants with RW is controversial, with reported benefits in infants with multiple trigger wheeze but little effect in episodic viral wheeze, ${ }^{15} 16$ this study shows that ICS are commonly prescribed to even the youngest infants with wheeze. 
Table 2 Reported medications and other variables (\%) in infants with recurrent wheezing during the first year of life $(n=6127)$

\begin{tabular}{|c|c|c|c|c|c|c|c|c|c|}
\hline & Inhaled BD & ICS & LTRA $\ddagger$ & $\begin{array}{l}\text { URTI in } \\
\text { first } 3 \\
\text { months }\end{array}$ & $\begin{array}{l}\text { Parental } \\
\text { asthma }\end{array}$ & $\begin{array}{l}\text { Frequent sleep } \\
\text { disturbance* }\end{array}$ & $\begin{array}{l}\text { Severe } \\
\text { episode }\end{array}$ & $\begin{array}{l}\text { Visits } \\
\text { to ED }\end{array}$ & $\begin{array}{l}\text { Admissions } \\
\text { to hospital }\end{array}$ \\
\hline \multicolumn{10}{|l|}{ Chile } \\
\hline Santiago & 99.4 & 56.3 & 5.0 & 68.2 & 13.0 & 18.4 & 55.2 & 65.5 & 22.1 \\
\hline Valdivia & 98.5 & 47.1 & 4.6 & 67.5 & 18.5 & 21.0 & 59.0 & 74.0 & 36.4 \\
\hline \multicolumn{10}{|l|}{ Brazil } \\
\hline Fortaleza $†$ & 87.4 & 23.1 & 0.5 & 52.7 & - & 38.6 & 59.6 & 73.8 & 24.7 \\
\hline Recife† & 94.7 & 28.2 & 3.0 & 56.2 & - & 33.5 & 66.2 & 87.5 & 23.7 \\
\hline Belo Horizonte & 89.4 & 49.8 & 13.3 & 46.8 & 37.8 & 32.8 & 56.3 & 74.3 & 33.1 \\
\hline Belem $†$ & $92.6 \dagger$ & 32.2 & 2.4 & 56.8 & 20.9 & 30.1 & 57.1 & 72.7 & 22.4 \\
\hline Porto Alegre & 92.9 & 54.3 & 13.0 & 28.0 & 30.4 & 37.4 & 71.9 & 83.5 & 33.5 \\
\hline Sao Paulo† & 89.9 & 15.8 & 3.3 & 49.0 & 13.3 & 34.9 & 53.5 & 72.0 & 23.0 \\
\hline Curitiba & 91.3 & 27.4 & 9.4 & 54.0 & 26.2 & 37.6 & 59.4 & 69.3 & 17.2 \\
\hline \multicolumn{10}{|l|}{ Colombia } \\
\hline Barranquilla & 87.7 & 56.4 & 16.7 & 59.7 & 25.6 & 21.0 & 79.7 & 82.0 & 46.8 \\
\hline \multicolumn{10}{|l|}{ Mexico } \\
\hline Merida & 100.0 & 28.1 & 50.0 & 3.1 & 28.2 & 46.9 & 37.5 & 25.0 & 21.9 \\
\hline \multicolumn{10}{|l|}{ Venezuela } \\
\hline Caracas & 92.8 & 77.6 & 43.6 & 60.5 & 43.7 & 21.0 & 74.6 & 70.7 & 34.7 \\
\hline $\begin{array}{l}\text { Latin America total, } \\
\text { mean }(95 \% \mathrm{Cl})\end{array}$ & $\begin{array}{l}92.9 \text { (92.2 to } \\
93.6)\end{array}$ & $\begin{array}{l}45.0 \text { (43.6 to } \\
46.4)\end{array}$ & $\begin{array}{l}11.5 \text { (10.6 to } \\
12.5)\end{array}$ & $\begin{array}{l}55.2 \text { (53.9 to } \\
56.5)\end{array}$ & $\begin{array}{l}25.0(23.7 \text { to } \\
26.3)\end{array}$ & 29.1 (28.0 to 30.4$)$ & $\begin{array}{l}61.2 \text { (59.9 to } \\
62.4)\end{array}$ & $\begin{array}{l}73.3(72.1 \text { to } \\
74.4)\end{array}$ & $\begin{array}{l}28.4(27.3 \text { to } \\
29.6)\end{array}$ \\
\hline \multicolumn{10}{|l|}{ Spain } \\
\hline Bilbao & 76.4 & 31.7 & 14.5 & 27.7 & 15.1 & 9.6 & 29.6 & 47.2 & 8.9 \\
\hline Cartagena & 82.7 & 73.3 & 31.4 & 55.7 & 22.2 & 25.1 & 51.6 & 58.8 & 12.8 \\
\hline La Coruña & 76.9 & 66.1 & 24.0 & 45.4 & 14.2 & 18.0 & 43.4 & 52.5 & 15.3 \\
\hline Valencia & 88.6 & 57.0 & 19.5 & 47.6 & 15.0 & 17.8 & 61.0 & 76.6 & 24.3 \\
\hline \multicolumn{10}{|l|}{ The Netherlands } \\
\hline Zwolle & 62.5 & 45.3 & 21.0 & 62.9 & 17.3 & 23.6 & 48.2 & 44.8 & 13.9 \\
\hline $\begin{array}{l}\text { Europe total, } \\
\text { mean }(95 \% \mathrm{Cl})\end{array}$ & $\begin{array}{l}77.1 \text { (73.9 to } \\
80.0)\end{array}$ & $\begin{array}{l}54.2 \text { (50.5 to } \\
57.9)\end{array}$ & $\begin{array}{l}22.1(19.1 \text { to } \\
25.5)\end{array}$ & $\begin{array}{l}47.4 \text { (43.8 to } \\
51.0 \text { ) }\end{array}$ & $\begin{array}{l}17.1 \text { (14.6 to } \\
20.0)\end{array}$ & 18.8 (16.2 to 21.8$)$ & $\begin{array}{l}45.6 \text { (42.0 to } \\
49.2 \text { ) }\end{array}$ & $\begin{array}{l}54.8 \text { (51.2 to } \\
58.4)\end{array}$ & $\begin{array}{l}14.2 \text { (11.8 to } \\
16.9)\end{array}$ \\
\hline $\begin{array}{l}\text { Total, mean } \\
(95 \% \mathrm{Cl})\end{array}$ & $\begin{array}{l}91.1 \text { ( } 92.2 \text { to } \\
93.5)\end{array}$ & $\begin{array}{l}46.1 \text { ( } 44.8 \text { to } \\
47.4)\end{array}$ & $\begin{array}{l}12.9(12.0 \text { to } \\
13.8)\end{array}$ & $\begin{array}{l}54.3(53.0 \text { to } \\
55.5)\end{array}$ & $\begin{array}{l}23.8(22.7 \text { to } \\
25.0)\end{array}$ & $27.9(26.9$ to 29.1$)$ & $\begin{array}{l}59.4 \text { (58.1 to } \\
60.6)\end{array}$ & $\begin{array}{l}71.1 \text { (70.0 to } \\
72.3)\end{array}$ & $\begin{array}{l}26.8(25.7 \text { to } \\
27.9)\end{array}$ \\
\hline
\end{tabular}

*Sleep disturbance due to wheezing (more than 1 week per month, every month).

†Inhaled corticosteroids not available at primary care centres (public health system).

FLTRA were not available for free in Latin American centres.

$\mathrm{BD}$, bronchodilators; ED, emergency department; ICS, inhaled corticosteroids; LTRA, leukotriene receptor antagonists; URTI, upper respiratory tract infection.

There is consistent evidence to support the concept that viral respiratory infections by common respiratory viruses ${ }^{17}$ are able to induce immunological changes significantly related with a higher risk of RW during the first year. ${ }^{18} 19$ Furthermore, symptomatic rhinovirus illness during infancy is a significant risk factor for the development of preschool RW and asthma. ${ }^{20} 21$ In the present study, an URTI in the first 3 months of life was

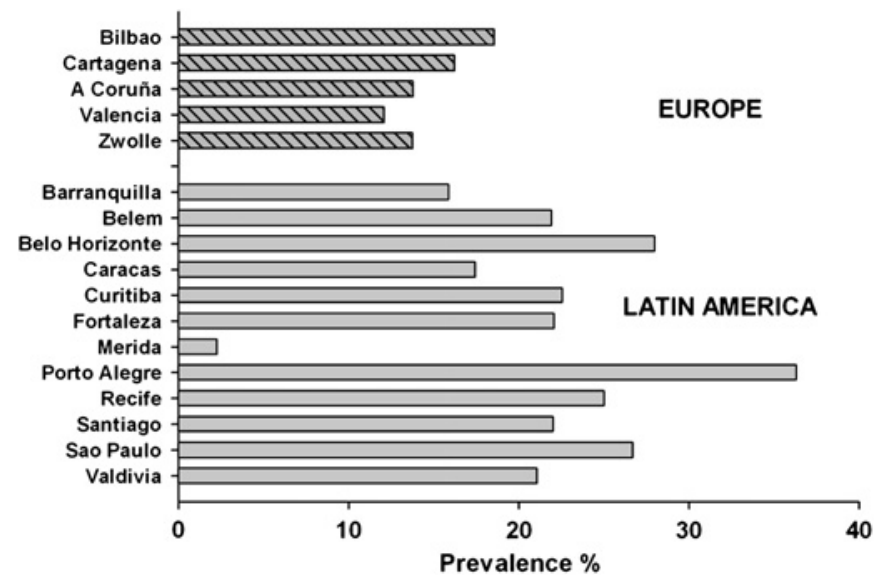

Figure 1 Prevalence of recurrent wheezing ( $\geq 3$ episodes of parentreported wheezing) in infants during the first year of life $(n=30093)$ in European and Latin American centres. a significant risk factor for RW later during the first year of life, supporting the idea that asthma-like responses may be set up in the first months and triggered by different factors-mainly common respiratory viruses ${ }^{17}$ - later in infancy and childhood. It is not possible to say whether viruses by themselves trigger a response favouring RW or simply reveal a genetic predisposition to this condition, or both.

Although a parental history of asthma and of personal eczema were frequently reported in infants with RW during the first year of life, no more than $40 \%$ of those infants were diagnosed with asthma although both conditions are mentioned as important elements to make the diagnosis of asthma in infants with repeated asthma-like symptoms. ${ }^{22-24}$

Low socioeconomic status has been shown to be a risk factor for persistent respiratory problems in infants such as wheezing and pneumonia ${ }^{6-8}$ and could be an important determinant for the lower prevalence and severity of RW in infants from EU centres compared with those from LA. However, the differences in the prevalence and severity of RW in infants within and between countries are probably due to complex and multifactorial environment-gene interactions that are distinctive for each locality and capable of modulating the airway responses from very early in life through to adulthood.

The very low and high prevalence of RW found in Merida (Mexico) (2.3\%) and Porto Alegre (Brazil) (36.3\%) cannot be satisfactorily explained by cross-sectional studies such as this one. It may be that local cultural, genetic and environmental 
Table 3 Wheezing-related factors for Latin American centres versus European centers (base)

\begin{tabular}{|c|c|c|}
\hline & Crude OR $(95 \% \mathrm{Cl})$ & p Value \\
\hline \multicolumn{3}{|l|}{ Whole sample } \\
\hline Wheezing once or more & $1.71(1.61$ to 1.83$)$ & $<0.0001$ \\
\hline Recurrent wheezing & $1.55(1.43$ to 1.69$)$ & $<0.0001$ \\
\hline URTI first 3 months of life & $1.43(1.34$ to 1.53$)$ & $<0.0001$ \\
\hline Wheezing first 3 months of life & 1.87 (1.69 to 2.05$)$ & $<0.0001$ \\
\hline Parental history of asthma & 1.94 (1.76 to 2.14$)$ & $<0.0001$ \\
\hline Physician-diagnosed asthma & 2.05 (1.79 to 2.35$)$ & $<0.0001$ \\
\hline Eczema & $5.48(5.05$ to 5.96$)$ & $<0.0001$ \\
\hline Inhaled bronchodilator & 1.88 (1.75 to 2.01$)$ & $<0.0001$ \\
\hline Inhaled corticosteroids & $1.03(0.95$ to 1.27$)$ & $=0.48$ \\
\hline Leukotriene receptor antagonist & $0.52(0.46$ to 0.59$)$ & $<0.0001$ \\
\hline Hospital admission due to wheezing & 2.76 (2.38 to 3.19$)$ & $<0.0001$ \\
\hline ED visit due to wheezing & 2.03 (1.87 to 2.19$)$ & $<0.0001$ \\
\hline Severe wheezing episode & 2.12 (1.94 to 2.32$)$ & $<0.0001$ \\
\hline $\begin{array}{l}\text { Frequent sleep disturbance due to } \\
\text { wheezing }\end{array}$ & 1.89 (1.65 to 2.17$)$ & $<0.0001$ \\
\hline \multicolumn{3}{|l|}{ Recurrent wheezing } \\
\hline URTI first 3 months of life & 1.39 (1.19 to 1.62$)$ & $<0.0001$ \\
\hline Wheezing first 3 months of life & $1.59(1.36$ to 1.87$)$ & $<0.0001$ \\
\hline Parental history of asthma & 1.89 (1.46 to 2.42$)$ & $<0.0001$ \\
\hline Physician-diagnosed asthma & 1.35 (1.23 to 1.63$)$ & $=0.0014$ \\
\hline Eczema & 4.75 (3.98 to 5.66$)$ & $<0.0001$ \\
\hline Inhaled bronchodilator & 4.17 (3.41 to 5.10$)$ & $<0.0001$ \\
\hline Inhaled corticosteroids & $0.68(0.58$ to 0.79$)$ & $<0.0001$ \\
\hline Leukotriene receptor antagonist & $0.45(0.37$ to 0.56$)$ & $<0.0001$ \\
\hline Hospital admission due to wheezing & 2.43 (1.96 to 3.01$)$ & $<0.0001$ \\
\hline ED visit due to wheezing & 2.29 (1.96 to 2.68$)$ & $<0.0001$ \\
\hline Severe wheezing episode & 1.95 (1.67 to 2.28$)$ & $<0.0001$ \\
\hline $\begin{array}{l}\text { Frequent sleep disturbance due to } \\
\text { wheezing }\end{array}$ & 1.81 (1.49 to 2.19$)$ & $<0.0001$ \\
\hline
\end{tabular}

$E D$, emergency department; URTI, upper respiratory tract infection.

risk/protective factors as well as methodological issues (low comprehension of questions by an important number of parents) are responsible for these findings. However, infants in Merida (Mexico) and Porto Alegre (Brazil) might genuinely represent the lower and upper range of the prevalence distribution spectrum of RW in the region, but this needs to be confirmed by further studies.

Apart from the limitations inherent to all cross-sectional studies, the present study in infants during the first year of life has the potential limitation of using a parental report instead of a physician's report. However, parental report of wheezing versus clinical examination was previously validated in infants from LA attending an ED with acute wheezing episodes, ${ }^{12}$ and also against examination by a paediatric thoracic physician and clinical records in infants with RW exacerbations followed up in specialised units in LA and Spain. ${ }^{11}$ The present study could not include centres from Portugal to compare with centres from Brazil; however, the prevalence of asthma in children from the Iberian Peninsula (Spain and Portugal) is very similar. ${ }^{9} 10$ The effect of an eventual yearly variation of the viral season (autumn-winter) on the prevalence of RW may also be considered as a limitation. Nevertheless, the difference found in this regard was quite small and non-significant. The latter would also support the consistency of the methodology used.

The strengths of the present study include its populationbased sampling strategy, large sample size, relatively high response rate and the inclusion of centres with different cultural and socioeconomic levels, thus making the results representative of the participating countries and regions. In addition, the EISL provides previously lacking comparative epidemiological infor- mation on RW during the first year of life on an international scale. The parent-reported information on wheezing occurring during the first year of life of the infants and collected when the infants were aged 12-15 months may decrease the chance of maternal recall bias in this study.

Our results suggest that there is room for improvement in the implementation of efficient strategies for the education and management of RW directed to parents and health personnel. It is likely that increasing the awareness of identifying and managing infants with RW, especially those with troublesome symptoms, may result in a decrease in the prevalence of severe episodes, visits to the ED and admissions to hospital.

In conclusion, the present study shows that the prevalence of RW during the first year of life is high in most centres and significantly variable, with a clear trend to be higher and more severe in LA than in EU. In spite of the high prevalence of RW, visits to the ED and admissions to hospital due to wheezing, a relatively infrequent use of ICS in infants with severe disease was reported in a considerable proportion of those infants. The present findings cast some doubts on the 'benign' course and presentation of RW during the first year of life in both affluent and non-affluent countries, and suggest the need for changes in the current approach to the diagnosis and management of RW in order to improve the important deleterious effect of this condition on the quality of life of infants and parents.

Acknowledgements We are grateful to the parents who participated with their infants in the International Study of Wheezing in Infants (EISL); the collaboration and assistance provided by the staff of the Primary Care Health centres; and Mr Anthony Carlson for his correction of the English language of this paper

EISL Study Group Manuel Baeza-Bacab, (México, Mérida); Álvaro Madeiro Leite, Olivia Costa Bessa (Brazil Fortaleza); Elaine Xavier Prestes (Brazil, Belem); Emanuel Sarinho, Décio Medeiros (Brazil, Recife); Paulo Camargos, María Jussara Fernández-Fontes, Wilson Rocha (Brazil, Bello Horizonte); Dirceu Solé, Caroline Della Bianca (Brazil, São Paulo); Nelson Rosario Herberto Chong (Brazil, Curitiba); Gilberto B Fischer (Brazil, Porto Alegre); Eduardo Cepeda (Colombia, Barranquilla); Oscar Aldrey, Arnaldo Capriles (Venezuela, Caracas); Javier Mallol, Viviana Aguirre, Alejandro Gallardo (Chile, Santiago); Mario Calvo (Chile, Valdivia); Luis García-Marcos, Antonela Martínez-Torres, Virginia Pérez-Fernández, (España, Murcia); Carlos González-Díaz, Andrés González Hermosa (España, Bilbao); Ángel López-Silvarrey Varela (España, La Coruña); María Morales Suárez-Varela (España, Valencia); Paul L P Brand, Chantal A N Visser (Zwolle, The Netherlands).

\section{Competing interests None.}

Patient consent Parents or guardians who agreed to participate in the study filled in the questionnaire after reading and signing a fully informed written consent form.

Ethics approval This study was conducted with the approval of the Scientific Ethics Committee, Chilean Ministry of Health, Southern Metropolitan Area of Santiago de Chile (Chile), the Ethics Committee of the University of Murcia (Spain) for all Spanish centres, and the respective Ethics Committees for the rest of the participating centres.

Provenance and peer review Not commissioned; externally peer reviewed.

\section{REFERENCES}

1. Oostenbrink R, Jansingh-Piepers $E M$, Raat $H$, et al. Health-related quality of life of pre-school children with wheezing illness. Pediatr Pulmonol 2006;41:993-1000.

2. Stevens CA, Turner D, Kuehni CE, et al. The economic impact of preschool asthma and wheeze. Eur Respir J 2003;21:1000-6.

3. de Jong BM, van der Ent CK, van Putte Katier N, et al. Determinants of health care utilization for respiratory symptoms in the first year of life. Med Care 2007:45:746-52

4. Bisgaard H, Szefler S. Prevalence of asthma-like symptoms in young children. Pediatr Pulmonol 2007;42:723-8.

5. Kuehni CE, Strippoli MP, Low N, et al. Wheeze and asthma prevalence and related health-service use in white and South Asian pre-schoolchildren in the United Kingdom. Clin Exp Allergy 2007;37:1738-46.

6. Mallol J, Andrade R, Auger F, et al. Wheezing during the first year of life in infants from low-income population: a descriptive study. Allergol Immunopathol (Madr) 2005;33:257-63.

7. Margolis PA, Greenberg RA, Keyes LL, et al. Lower respiratory illness in infants and low socioeconomic status. Am J Public Health 1992;82:1119-26. 
8. Klinnert MD, Price MR, Liu AH, et al. Morbidity patterns among low-income wheezing infants. Pediatrics 2003;112:49-57.

9. International Study of Asthma and Allergies in Childhood (ISAAC)

Steering Committee. Worldwide variation in prevalence of symptoms of asthma. Allergic rhinoconjunctivitis. and atopic eczema: ISAAC. Lancet 1998;351:1225-32.

10. Pearce N, Aitt-Khaled N, Beasley R, et al. Worldwide trends in the prevalence of asthma symptoms: phase III of the International Study of Asthma and Allergies in Childhood (ISAAC). Thorax 2007:62:758-66.

11. Mallol J, García-Marcos L, Aguirre V, et al. The International Study of Wheezing in Infants: questionnaire validation. Int Arch Allergy Immunol 2007;144:44-50.

12. Chong Neto HJ, Rosario N, Dela Bianca AC, et al. Validation of a questionnaire for epidemiologic studies of wheezing in infants. Pediatr Allergy Immunol 2007:18:86-7.

13. Ellwood P, Asher MI, Beasley R, et al. The International Study of Asthma and Allergies in Childhood (ISAAC): phase three rationale and methods. Int J Tuberc Lung Dis 2005:9:10-16.

14. Asher M, Keil U, Anderson $\mathrm{H}$, et al. International Study of Asthma and Allergies in Childhood (ISAAC): rationale and methods. Eur Respir J 1995;8:483-91.

15. Brand PL, Baraldi E, Bisgaard $\mathrm{H}$, et al. Definition, assessment and treatment of wheezing disorders in preschool children: an evidence-based approach. Eur Respir J 2008;32:1096-110.

16. Kaditis AG, Winnie G, Syrogiannopoulos GA. Anti-inflammatory pharmacotherapy for wheezing in preschool children. Pediatr Pulmonol 2007;42:407-20.
17. Legg JP, Warner JA Johnston SL, et al. Frequency of detection of picornaviruses and seven other respiratory pathogens in infants. Pediatr Infect Dis J 2005;24:611-16.

18. Gern JE, Brooks GD, Meyer P, et al. Bidirectional interactions between viral respiratory illnesses and cytokine responses in the first year of life. J Allergy Clin Immunol 2006;117:72-8.

19. Lemanske RF Jr, Jackson DJ, Gangnon RE, et al. Rhinovirus illnesses during infancy predict subsequent childhood wheezing. J Allergy Clin Immunol 2005;116:571-7.

20. Kotaniemi-Syrjänen A, Vainionpää R, Reijonen TM, et al. Rhinovirus-induced wheezing in infancy - the first sign of childhood asthma? J Allergy Clin Immunol 2003;111:66-71

21. Johnston SL, Pattemore PK, Sanderson G, et al. Community study of role of viral infections in exacerbations of asthma in 9-11 year old children. BMJ 1995;310:1225-8.

22. British Thoracic Society, Scottish Intercollegiate Guidelines Network (SIGN). British guideline on the management of asthma, 2008. http://www.britthoracic.org.uk/Portals/0/Clinical\%20Information/Asthma/Guidelines/ asthma final2008.pdf (accessed Jun 2010).

23. National Asthma Education and Prevention Program (NAEPP), National Heart, Lung, and Blood Institute (NHLBI), National Institutes of Health (NIH). Guidelines for the diagnosis and management of asthma, 2007. http://www.nhlbi.nih. gov/guidelines/asthma/08 sec4 It 0-11.pdf (accessed Jun 2010)

24. Castro-Rodríguez JA, Holberg $\mathrm{CJ}$, Wright AL, et al. A clinical index to define risk of asthma in young children with recurrent wheezing. Am J Respir Crit Care Med 2000;162:1403-6.

\section{Pulmonary puzzle}

\section{Persistent cough: an unusual cause}

A 55-year-old Caucasian man who worked in the recycling industry presented with a 7-month history of non-productive cough and no other symptoms. He had no significant previous medical history and took no medications. He had never smoked and had no history of travel outside the UK. He described symptoms of a lower respiratory tract infection 5 months previously which had been treated with antibiotics and steroids. A chest $\mathrm{x}$-ray at the time had shown consolidation consistent

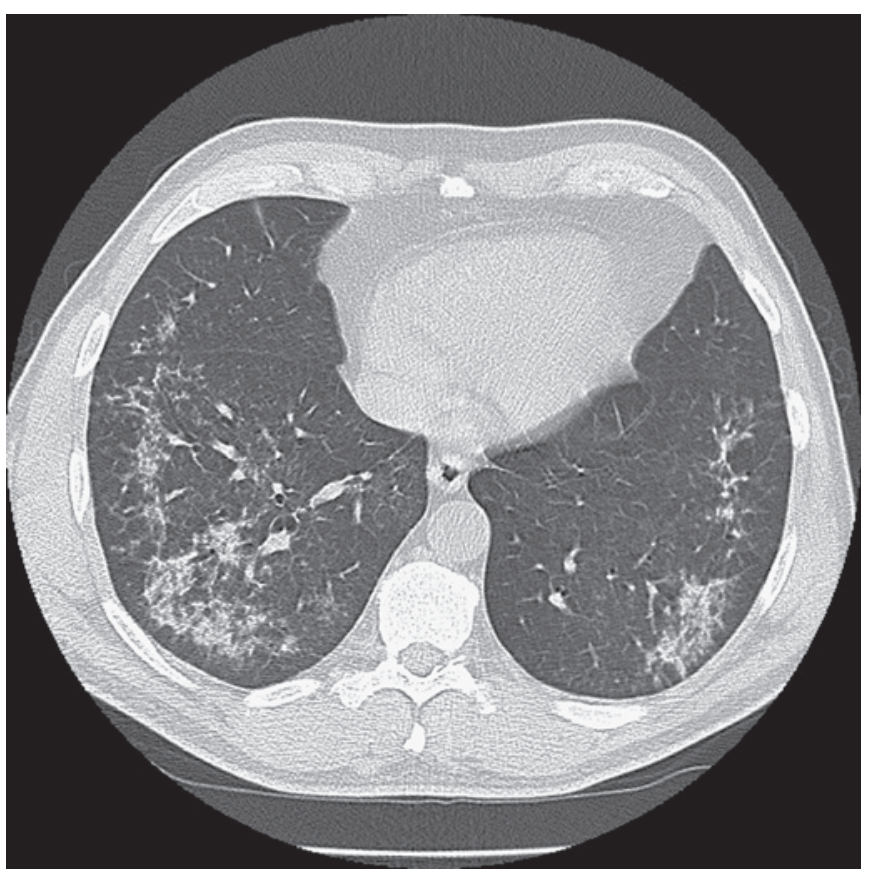

Figure 1 High-resolution CT scan showing bilateral patchy bronchocentric consolidation. with infection which had subsequently resolved. Physical examination was normal.

Spirometry and transfer factor were normal. Full blood count showed isolated eosinophilia of $12.7 \times 10^{-9} / 1$. The blood film revealed an unremarkable cell morphology. The erythrocyte sedimentation rate was elevated at $92 \mathrm{~mm} / \mathrm{h}$. Urea and electrolytes, liver function tests and serum immunoglobulin E (IgE) were normal. Aspergillus precipitins, antineutrophil cytoplasmic antibodies, rheumatoid factor and antinuclear antibodies were negative. Stool culture and microscopy were negative. A repeat chest X-ray was normal but a high-resolution CT scan showed bilateral patchy bronchocentric consolidation (figure 1) and mild splenomegaly. Bronchoscopy revealed no endobronchial abnormality with negative results for culture and cytology.

The patient's cough became so debilitating that he was unable to work. His eosinophil count rose to $18 \times 10^{-9} / 1$ and he was referred for haematology review. A bone marrow trephine was performed and peripheral blood was sent for cytogenetic testing which gave the diagnosis. Within 2 weeks of commencing treatment his cough had resolved and his eosinophil count was 0 .

\section{QUESTION}

What is the diagnosis and what treatment caused his dramatic clinical improvement?

See page 1024 for answer

\section{Bethan Barker ${ }^{1}$, Harmesh Moudgil', Gareth Slocombe ${ }^{3}$, Koottalai Srinivasan ${ }^{2}$}

${ }^{1}$ Department of Respiratory Medicine, Birmingham Heartlands Hospital, Bordesley Green East, Birmingham, UK; ${ }^{2}$ Department of Respiratory Medicine, Princess Royal Hospital, Apley Castle, Telford, UK; ${ }^{3}$ Department of Haematology, Princess Royal Hospital, Apley Castle, Telford, UK

Correspondence to Dr Bethan Barker, Department of Respiratory Medicine, Birmingham Heartlands Hospital, Bordesley Green East, Birmingham B9 5SS, UK; bethanbarker@hotmail.com

\section{Competing interests None}

Patient consent Obtained

Provenance and peer review Not commissioned; externally peer reviewed. Thorax 2010:65:1009. doi:10.1136/thx.2010.135251 